\title{
Influence of Temperature and Wetness Periods on the Development of Stemphylium Blight on Lentil
}

\author{
E. Mwakutuya, Dow AgroSciences, 9330 Zionsville Rd., Indianapolis, IN 46241, USA; and S. Banniza, Crop De- \\ velopment Centre, University of Saskatchewan, 51 Campus Drive, Saskatoon, Saskatchewan S7N 5A8, Canada
}

\begin{abstract}
Mwakutuya, E., and Banniza, S. 2010. Influence of temperature and wetness periods on the development of Stemphylium blight on lentil. Plant Dis. 94:1219-1224.

Stemphylium blight of lentil (Lens culinaris subsp. culinaris) caused by Stemphylium botryosum has become more prevalent in the Canadian prairies. Germination of conidia, appressorium formation, and infection of lentil plants were evaluated under controlled conditions at temperatures from 5 to $30^{\circ} \mathrm{C}$ and increasing incubation periods under wet conditions to elucidate the epidemiology of this disease. On glass slides, conidial germination increased steadily with temperature up to 25 and $30^{\circ} \mathrm{C}$, and reached more than $80 \%$ after $20 \mathrm{~h}$ at these temperatures, compared with around $30 \%$ at $5^{\circ} \mathrm{C}$. The response of germination on glass slides to temperature was nonlinear, as evident in significant linear, quadratic single factor, and linear, quadratic, and cubic cross factor temperature effects in the model. On lentil leaves, $18 \%$ of conidia had germinated after $2 \mathrm{~h}$ of incubation at $25^{\circ} \mathrm{C}$, and a few germ tubes penetrated into the tissue through stomata. Germination reached $89 \%$ after $12 \mathrm{~h}$, and $12 \%$ of germ tubes had penetrated into the leaves. Stemphylium blight severity reached more than $80 \%$ at 25 and $30^{\circ} \mathrm{C}$ with leaf wetness periods of 48 h. A simple logistic model with linear temperature, leaf wetness period, and cross factor effects described disease development on lentil plants.
\end{abstract}

Lentil (Lens culinaris Medik. subsp. culinaris) is mainly grown in the cooler temperate zones of the old world, with more recent introductions into Australia, Canada, New Zealand, and the United States (6). Diseases are a major constraint to the production of lentil in the Canadian prairies. Anthracnose (Colletotrichum truncatum (Schwein.) Andrus \& W.D. Moore), Ascochyta blight (Ascochyta lentis Vassilievsky), and Botrytis stem and pod rot (Botrytis cinerea Pers.:Fr.) of lentil have been associated with yield losses of up to $60 \%$ depending on the disease and prevailing conditions (26). Infection by Stemphylium botryosum Wallr., causal agent of Stemphylium blight of lentil, has been observed more frequently in recent years, most notably on lentil seed tested for various fungal infections in commercial seed testing laboratories (27). Initial symptoms on leaves consist of small, light beige lesions that enlarge and coalesce, thus blighting entire leaves and shoots. Pedicels and flowers can also be infected, the latter resulting in flower abortion. Symptoms are prominent in the upper canopy, but entire plants can be blighted under severe infestations. Significant leaf drop, loss in biomass

Corresponding author: S. Banniza

E-mail: sabine.banniza@usask.ca

Accepted for publication 11 June 2010.

doi:10.1094/PDIS-12-09-0804

(C) 2010 The American Phytopathological Society and seed yield, and a reduction in seed size can occur. Infected seeds are often stained and can have low germination rates. The pathogen spreads by airborne conidia that develop in successive generations on distinct conidiophores on the leaf surface.

$S$. botryosum can infect a wide range of plant species under different environmental conditions. Host plants other than lentil are spinach (Spinacia oleracea L.) (18), onion (Allium cepa L.) $(1,17)$, tomato (Lycopersicon esculentum L.) (5), alfalfa (Medicago sativa L.) (8), and clover (Trifolium repens L.) (13). Whether host specialization occurs among isolates from the different host plants has not been explored in detail. Crop devastations in lentil due to Stemphylium blight have been reported from Bangladesh and India, where this disease is a major constraint to production $(2,16,30)$. The economic impact of this disease in Canadian lentil production has not been assessed, and very little is known about the biology of the pathogen in this environment. In many years, Stemphylium blight appears toward the end of the lentil growing season in Canada, so that the main impact is to hasten desiccation. Early infection observed in some years may, however, result in yield reductions and loss of seed quality. Preliminary experiments under controlled conditions have shown that seed size can be significantly reduced and seed staining similar to that caused by Ascochyta lentis can be induced by $S$. botryosum (S. Banniza, unpublished data).

Temperature and moisture are primary environmental factors affecting conidial germination of $S$. botryosum and further development of disease on other hosts $(4,5,11)$. The presence of free water on the leaf surface at optimal temperatures promoted germination and disease development of Stemphylium spp. on clover (7). In alfalfa, geographically separated warm and cool biotypes of $S$. botryosum have been identified (9). The prevalence of moderate to warm temperatures below $25^{\circ} \mathrm{C}$ and wetness duration longer than $24 \mathrm{~h}$ favor the appearance, development, and spread of Stemphylium blight in northeastern India and in west-central Bangladesh $(3,30)$. In southern Bangladesh, higher temperatures up to $35^{\circ} \mathrm{C}$, maximum and minimum relative humidity (RH) of 78 to $100 \%$ and 48 to $80 \%$, and 1.2 to $14.8 \mathrm{~mm}$ of precipitation through periodic rainfalls were considered favorable for Stemphylium blight severity (16). However, detailed studies investigating the effects of temperature and moisture on conidial germination of Stemphylium spp. are lacking. Data on the closely related genus Alternaria suggest that conidial germination occurs at temperatures ranging from 3 to $35^{\circ} \mathrm{C}$, and is initiated within 1 to $3 \mathrm{~h}$ of incubation at optimal temperatures $(31,33)$. Conidia of Alternaria spp. have the ability to germinate at $100 \%$ humidity, whereas those of Stemphylium spp. appear to require the presence of free water (5). In some host species, Stemphylium spp. are able to penetrate directly through the epidermis or indirectly through the stomata, whereas in others appressoria are formed $(1,32)$. For example, $S$. vesicarium differentiates appressoria on onion leaves (1), but not on asparagus (12).

It is currently not understood what factors have triggered the higher occurrence of Stemphylium blight on lentil in the Canadian prairies in recent years. Specific effects of environmental factors on $S$. botryosum of lentil in the semiarid climate of the Canadian prairies are not known; hence this study was initiated with the objective to gain a better understanding of the epidemiology of this pathogen. As a first step, experiments were conducted to determine the effect of temperature and leaf wetness duration on conidial germination, leaf penetration, and the development of Stemphylium blight on a susceptible lentil cultivar. Data generated from these experiments were utilized to model germination and disease development under varying environmental conditions. 


\section{MATERIALS AND METHODS}

Inoculum production. Two monoconidial isolates of $S$. botryosum (SB9 and SB19) were selected from a collection of isolates obtained from naturally infected lentil plants collected at different locations in the province of Saskatchewan, Canada, where most Canadian lentil production is concentrated. Preliminary experiments on a larger set of isolates had shown that yields of conidia in general were low, irrespective of the growth medium used (S. Banniza, unpublished data). SB9 and SB19 were among the better sporulating isolates, and both were used for the germination experiments on glass slides. SB19 with slightly higher conidiation was selected for further plant inoculations, which required greater amounts of inoculum.

Stock cultures of monoconidial isolates were stored in sterile deionized water at 7 $\pm 2^{\circ} \mathrm{C}$, and all cultures used in these experiments were derived from a single stock. Isolates were grown on V8 juice/potato dextrose medium $(150 \mathrm{ml}$ of V8 juice [Campbell Soup Company, Camden, NJ, USA], $10 \mathrm{~g}$ of potato dextrose agar [Difco, Becton Dickinson and Co., Franklin Lake, NJ, USA], $3 \mathrm{~g}$ of calcium carbonate, and $850 \mathrm{ml}$ of distilled water) in petri dishes. To achieve optimum sporulation, cultures were incubated for 7 to 10 days at $27^{\circ} \mathrm{C}$ under cool fluorescent light $\left(44 \mu \mathrm{mol} \mathrm{m} \mathrm{m}^{-2} \mathrm{~s}^{-1}\right)$ and a photoperiod of $16 \mathrm{~h}$ light per day. Conidia were collected from petri dishes by flooding the plates with deionized water and gently dislodging the conidia with a soft brush. A drop of the surfactant Tween 20 (Sigma, Saint Louis, MO, USA) was added to every $1,000 \mathrm{ml}$ of deionized water. All conidial suspensions were processed simultaneously. The concentration of conidia was determined by counting on a Neubauer hemacytometer and was adjusted to the desired concentration by diluting with deionized water.

Plant material. The small green lentil cultivar CDC Milestone was grown in a growth chamber (Model GR 48, Conviron, Winnipeg, $\mathrm{MB}$, Canada) at $25^{\circ} \mathrm{C}$ with a photoperiod of $16 \mathrm{~h}$ light per day provided by fluorescent lamps with light intensities of between 315 and $325 \mu \mathrm{mol} \mathrm{m} \mathrm{m}^{-2} \mathrm{~s}^{-1}$. Preliminary experiments on disease resistance of lentil cultivars to Stemphylium blight had confirmed that CDC Milestone was susceptible to the disease (S. Banniza, unpublished data). The seeds were sown in 10-cm-diameter plastic pots filled with a commercial potting mix (Terralite RediEarth, Scotts Sierra Horticultural Products Co., Marysville, OH, USA), and the seedlings were thinned to four plants per pot. The plants were fertilized with complete fertilizer solution (20:20:20 NPK + micronutrients) (Plant-Prod All Purpose 20-2020, Plant Products Co. Ltd., Brampton, ON, Canada) 2 weeks after planting. Three-week-old whole lentil plants were inoculated in all the experiments as de- scribed below, and pots were arbitrarily assigned to treatments.

Effect of temperature and incubation period on conidial germination. All germination tests were carried out on culture slides with single depressions of $18 \mathrm{~mm}$ diameter (Culture Micro Slide, Single Depression, VWR, Mississauga, ON, Canada) under laboratory conditions. Conidial suspensions of $5 \times 10^{4}$ conidia per $\mathrm{ml}$ of isolates SB9 and SB19 were prepared from 7-day-old cultures. A high concentration of conidia was used to simplify the counting of germinated spores. An aliquot of $100 \mu \mathrm{l}$ of conidial suspension was evenly spread over each well slide depression before placing them on top of moistened filter paper in labeled petri dishes. Dishes were kept in plastic trays lined with moistened paper towels to maintain high humidity and were incubated at temperatures of 5 , $10,15,20,25$, and $30^{\circ} \mathrm{C}$ in incubators (Sanyo Versatile Environmental Test Chamber Model MLR-350H, Sanyo Electric Co., Ltd., Gunma, Japan) under continuous cool fluorescent light $\left(32 \mu \mathrm{mol} \mathrm{m} \mathrm{m}^{-2}\right.$ $\mathrm{s}^{-1}$ ). Preliminary studies had shown that light and the age of the fungal cultures had no effect on conidial germination of $S$. botryosum (data not presented). Germination of conidia was assessed through destructive sampling at 2-h intervals for $20 \mathrm{~h}$ by removing four replicate slides of each isolate and temperature treatment. With the aid of a light microscope (Nikon Microphot FXA, Japan) at $\times 100$ magnification, conidial germination was determined by evaluating 100 conidia within several fields of view selected arbitrarily from left to right across each slide. Conidia were considered to have germinated when the germ tube was at least half the width of the conidium (10). The number of germinated conidia was expressed as a percentage of the total number of conidia counted. The experiment was arranged as a split-plot with temperature as the main plot and leaf wetness duration as the subplot. The experiment was conducted twice.

All statistical data analyses of these and subsequent experiments were conducted in SAS (Version 9.1, SAS Institute, Cary, NC, USA).

Data of conidial germination on glass slides of both isolates were analyzed by repeated measures analysis using the mixed model procedure with the KenwardRoger correction (19). Heterogeneity of variances and dependencies among repeated measures were modeled by specifying a generalized first-order autoregressive structure with heterogeneous variances which had the best fit among several covariance structures tested (19) (data not presented). Simple, logistic, and negative exponential models were assessed for their goodness-of-fit based on visual evaluation of residuals (22). Neither the logistic nor the negative exponential model improved goodness-of-fit, so further analyses were conducted with untransformed data. Means were separated using Fisher's least significant differences.

Overall, germination of isolates responded similarly to temperature, so data were pooled and a response surface model for conidial germination as described by temperature and incubation time was developed. As before, a generalized firstorder autoregressive covariance structure was specified. Initially, a model was specified with linear, quadratic, cubic, and cross factor terms. Nonsignificant components of the model were deleted in subsequent steps, and models were compared based on Akaike's information criterion (AIC), the corrected AIC (AICC), and the Bayesian information criterion (BIC), as well as by visual assessment of residuals. Fixed effect estimates were obtained with the SOLUTION option in the model statement.

Infection studies of $S$. botryosum on lentil leaves. Microscopy studies on attached leaves of CDC Milestone were conducted to understand the infection process of $S$. botryosum. Eighteen pots with four plants each of CDC Milestone grown as described above were inoculated with isolate SB19 at $2 \times 10^{5}$ conidia per $\mathrm{ml}$. In preliminary experiments, this concentration had been identified as optimal for disease development (data not presented). A $\mathrm{CO}_{2}$ air brush (Model RUH8210, Oxygen regulator, Uniweld, USA) at a pressure of $138 \mathrm{kPa}$ was used to apply the spore suspension. Deionized water was sprayed on noninoculated control plants. Plants were incubated at $25^{\circ} \mathrm{C}$ in a mist tent within the growth chamber. Relative humidity was kept above $95 \%$ by saturating the air with water droplets from a humidifier (Humidifier model $7075 \mathrm{M}$, Sanford, NC, USA). Temperature and relative humidity were monitored using a HOBO data logger $\left(\mathrm{HOBO}^{\circledR} \mathrm{H} 8\right.$ Pro Series, Onset Computer Corporation, Bourne, MA, USA). Three arbitrarily selected pots were assigned to each of six treatments: 2 , $4,6,8,10$, and $12 \mathrm{~h}$ of incubation with continuous leaf wetness. At the end of each incubation period, more than 20 leaves were arbitrarily sampled from each of the three replicate pots assigned to each incubation treatment, and were stored separately for each pot in glass tubes containing a destaining solution of 3:1 glacial acetic acid and ethanol (Merck KGaA, Brampton, ON, Canada). Eight arbitrarily selected leaves of the 20 collected from each pot were examined under $\times 100 \mathrm{mag}$ nification of a Nikon Microphot-FXA microscope (Nikon Inc., New York, USA). The number of conidia that had germinated and the number of those that had invaded the leaves (through stomata or by direct penetration) were counted. Penetration by several germ tubes generated by one polyspermic conidium was counted as one. Data were expressed as percentage for statistical analysis. The experimental de- 
sign was a completely randomized design with three replications and two repetitions.

Numbers of germinated conidia and successful invasion from the leaf infection study were analyzed by simple linear regression with the regression procedure of SAS. The same set of data of isolate SB19 was extracted from the experiment on germination on glass slides, and was analyzed with the same procedure for the purpose of comparison.

Effect of leaf wetness duration and temperature on disease development. The experiment was conducted under controlled conditions in growth chambers (Model PGV 56, Conviron, Winnipeg, MB, Canada). Twenty-one-day-old plants of CDC Milestone were inoculated until runoff (approximately $5 \mathrm{ml}$ per plant) with a conidial suspension of isolate SB19 $(2 \times$ $10^{5}$ conidia per $\mathrm{ml}$ ) as described before, and pots were wrapped with polythene plastic sheets to promote high humidity. Deionized water was sprayed on noninoculated control plants. Plants were placed in mist tents at various incubation temperatures as described before. The chambers were operated at $10,15,20,25$, and $30^{\circ} \mathrm{C}$. The plants were exposed to leaf wetness periods of $0,2,4,6,8,10,12,24$, and 48 h. After removal from the mist tents, plants were allowed to dry and incubated until 14 days postinoculation in the same growth chamber under cool fluorescent light with light intensities of $315 \mu \mathrm{mol} \mathrm{m} \mathrm{m}^{-2} \mathrm{~s}^{-1}$ and at $85 \pm 3 \% \mathrm{RH}$ to promote disease development. The experiment was arranged as a split-plot with temperature as the main plot and leaf wetness duration as the subplot. The experiment was conducted twice.

Disease severity was recorded at 3, 7 , and 14 days postinoculation using the Horsfall-Barratt scale (15). Individual plants were assessed using the grades and data were transformed into percent disease using the ELANCO conversion.

Stemphylium blight severity on plants of lentil (cv. CDC Milestone) as described by temperature and leaf wetness period was assessed by repeated measures analysis using the mixed model procedure with the Kenward-Roger correction (19). Heterogeneous variances and dependencies among repeated measures were modeled by specifying a first-order antedependence structure that showed the best fit among several models evaluated, and accommodated unequal spacing in repeated measures $(19,29,34)$. Based on the shape of response curves of observed disease severity values, the fit of logistic, Gompertz, and Richards models were explored (22). The logistic model had the better fit (data not presented) and was used for detailed analyses. Means were separated using Fisher's least significant differences.

A response surface model for Stemphylium blight severity on plants of lentil cultivar CDC Milestone in response to temperature and leaf wetness was devel- oped based on the logistic model and an unstructured covariance matrix which had the best fit. The mixed model procedure was used, and as before a model was initially specified with linear, quadratic, cubic, and cross factor terms. Nonsignificant components of the model were deleted in subsequent steps, and models were compared based on AIC, AICC, and BIC, as well as residuals. Fixed effects estimates were obtained with the SOLUTION option in the model statement.

\section{RESULTS}

Effect of temperature and incubation period on conidial germination. In the presence of free water, conidia of $S$. botryosum germinated over a wide range of temperatures $\left(5\right.$ to $\left.30^{\circ} \mathrm{C}\right)$ (Fig. 1). Generally, the percentage of germinated conidia increased with temperature and incubation period. After $20 \mathrm{~h}$ of incubation, the conidial germination for the two isolates was above $30 \%$ at $5^{\circ} \mathrm{C}$ and above $80 \%$ at 25 or $30^{\circ} \mathrm{C}$. At least $10 \%$ of conidia germinated after $2 \mathrm{~h}$ at $5^{\circ} \mathrm{C}$, whereas over $40 \%$ had germinated at $30^{\circ} \mathrm{C}$ after the same period (Fig. 1).

Significant effects on germination were observed for isolates $(P=0.0201)$, temperature $(P<0.0001)$, incubation period
$(P<0.0001)$, and the isolate $\times$ temperature interaction $(P<0.0001)$. To explore differences between the isolates further, models were fitted for each temperature. Isolate SB9 had a somewhat higher germination rate at $5^{\circ} \mathrm{C}$ beyond $10 \mathrm{~h}$, and at $10^{\circ} \mathrm{C}$ beyond $18 \mathrm{~h}$ of incubation, whereas isolate SB19 had higher conidial germination during the first $10 \mathrm{~h}$ of incubation at 15 and $20^{\circ} \mathrm{C}$ (Fig. 1). SB19 also had higher conidial germination between 12 and $18 \mathrm{~h}$ of incubation at $25^{\circ} \mathrm{C}$ compared to $30^{\circ} \mathrm{C}$, but final germination after $20 \mathrm{~h}$ of incubation was similar.

Overall, germination trends over time for the two isolates were considered similar enough to pool data for further modeling. The relationship of temperature, incubation period, and conidial germination of $S$. botryosum was best described by the following model:

$$
\begin{aligned}
G & =b_{0}+b_{1} I+b_{2} I^{2}+b_{3} T+b_{4} T^{2}+b_{5} T I \\
& +b_{6} T^{2} I+b_{7} T^{3} I+E
\end{aligned}
$$

where $G$ is the proportion of germinated conidia, $T$ is temperature, and $I$ is incubation period. Although complex, the model showed a good fit overall, and the majority of predicted values were within $2 \%$ of the observed germination values (Fig. 2). The highest deviations were observed at $10^{\circ} \mathrm{C}$,

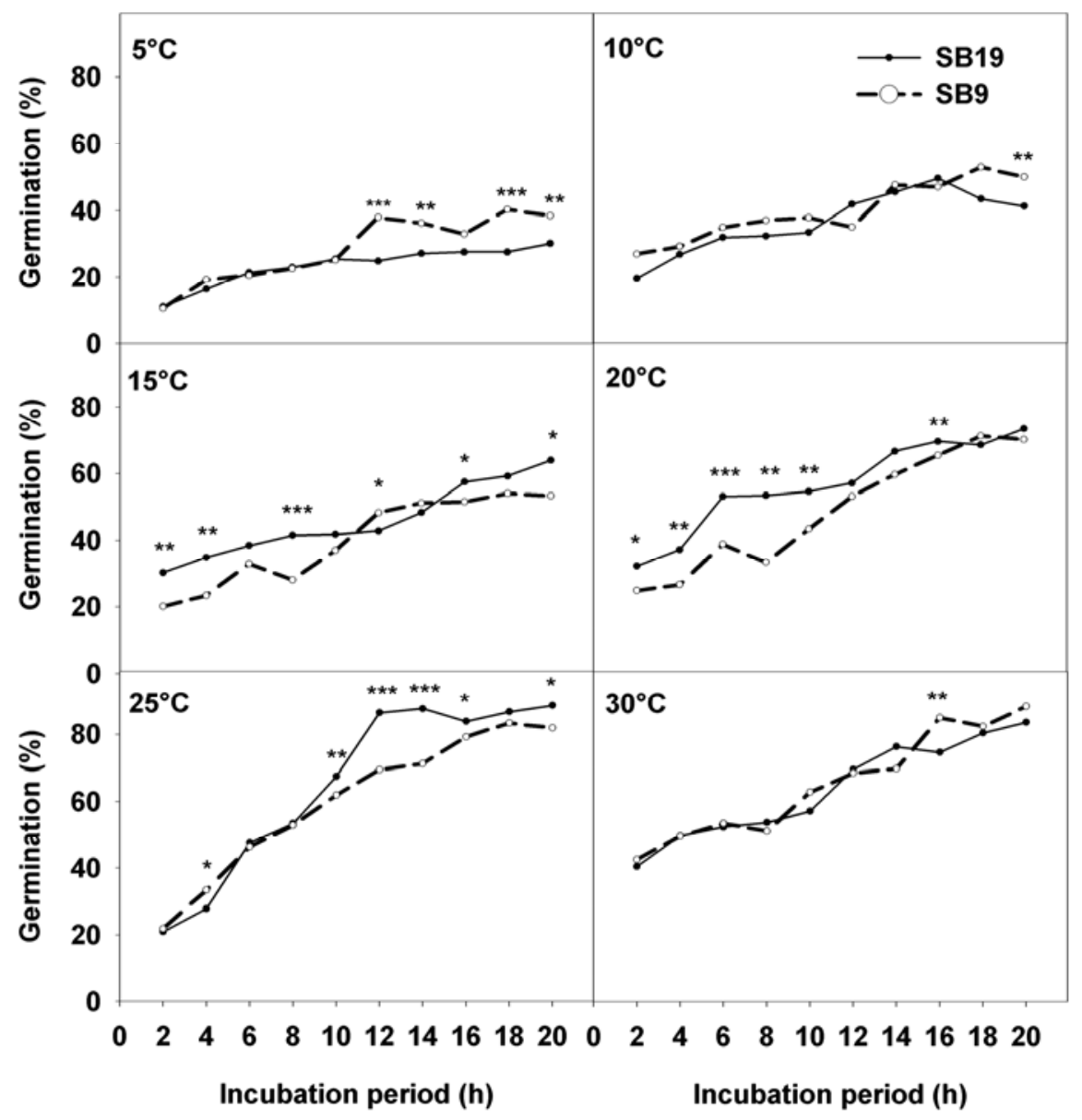

Fig. 1. Conidial germination of Stemphylium botryosum isolates SB19 and SB9 on glass slides in response to temperature and incubation period. Asterisks indicate significant differences between the isolates at $P \leq 0.05$ for *, $P \leq 0.01$ for $* *$, and $P<0.0001$ for $* * *$. 
where predicted germination was up to $7 \%$ lower than observed.

Infection studies of $S$. botryosum on lentil leaves. Germination occurred within the first $2 \mathrm{~h}$ of inoculation, and conidia were polyspermic with germ tubes developing randomly in different directions. Up to six germ tubes were observed developing from one conidium. Most penetrations of the leaf surface were through the stomata; however, germ tubes also passed close to or over stomata, suggesting that there was no specific orientation of germ tubes toward stomata. Appressorium for- mation was not observed in this experiment. The development of hyphae inside the leaf tissue was detectable after $12 \mathrm{~h}$. Percent germination and the number of successful penetrations increased linearly with wetness duration at $25^{\circ} \mathrm{C}(P<$ 0.0001 ) (Fig. 3). Germination of conidia had reached $88 \%$ after $12 \mathrm{~h}$ of incubation, and an average of 11 successful penetrations per leaflet were observed.

Effect of leaf wetness duration and temperature on disease development. Stemphylium blight was not observed on uninoculated plants, but the disease was

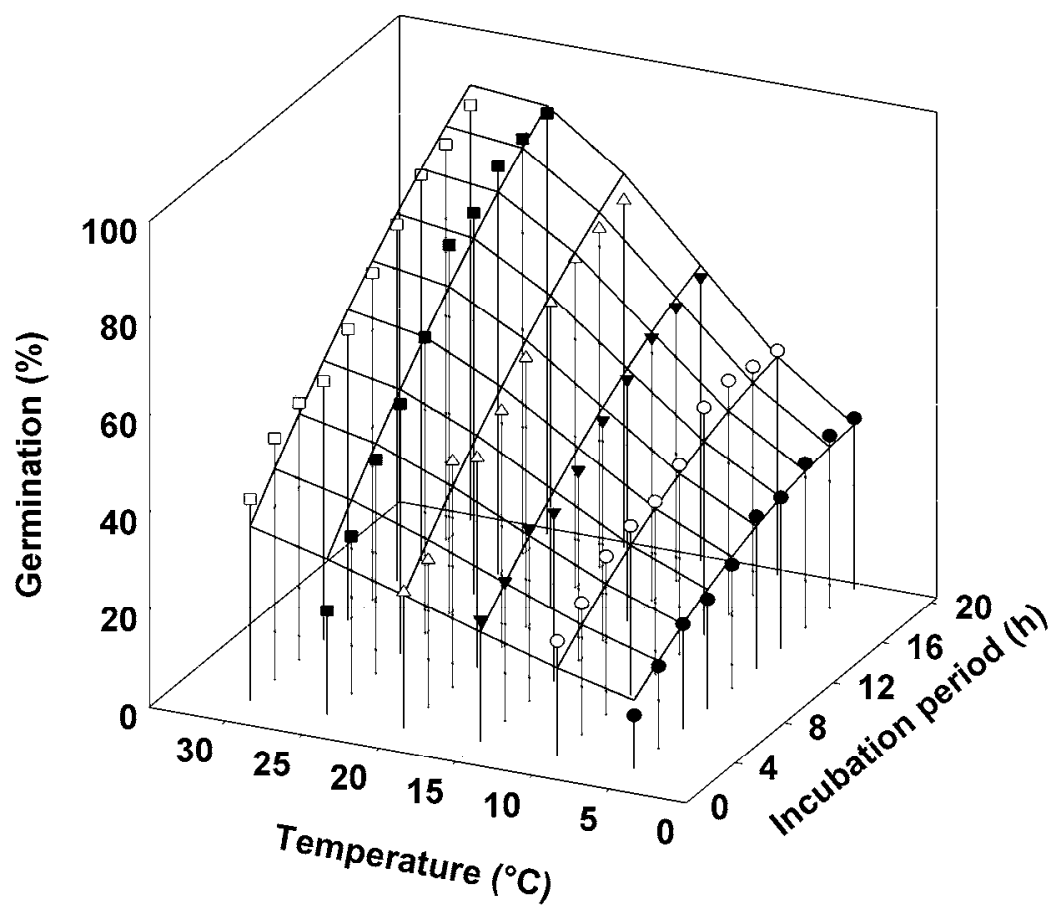

Fig. 2. Conidial germination $(G)$ of Stemphylium botryosum on glass slides in response to temperature $(T)$ and incubation period $(I)$. Symbols represent observed germination at $5,10,15,20,25$, and $30^{\circ} \mathrm{C}$. Response surface mesh plot represents predicted germination based on the polynomial function $G=$ $0.071710+0.02330 I-0.00054 I^{2}+0.00508 T+0.00006 T^{2}-0.00074 T I+0.00014 T^{2} I-3.23 E^{-6} T^{3} I$.

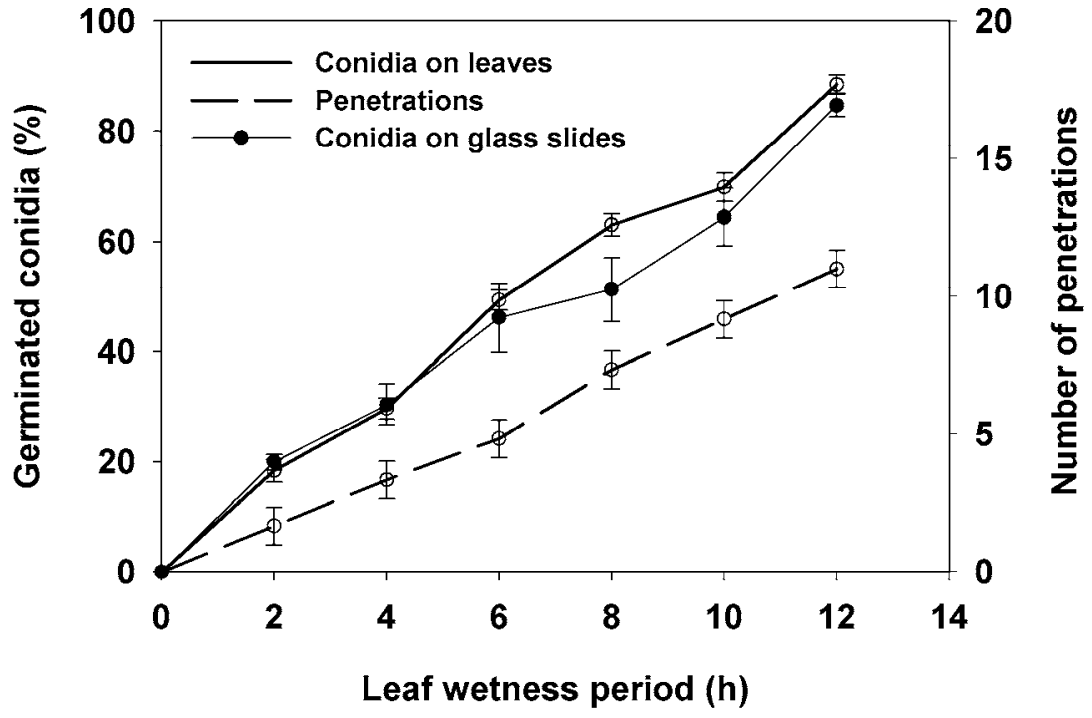

Fig. 3. Germination of conidia of Stemphylium botryosum isolate SB19 on attached leaves of lentil cultivar CDC Milestone and on glass slides, and penetration of the fungus into leaves in a growth chamber at $25^{\circ} \mathrm{C}$ during a 12 -h wetness period. prevalent on all inoculated plants. Temperature, leaf wetness period, and the interaction between these factors in the repeated measures analysis had significant effects on Stemphylium blight severity $(P$ $<0.0001)$. In general, there was a significant increase in disease severity with increasing leaf wetness duration (Fig. 4). Disease severity was lower on plants incubated at $10^{\circ} \mathrm{C}$ than on plants incubated at any other temperature except for plants incubated under dry conditions after inoculation $(0 \mathrm{~h})$ at 15 and $20^{\circ} \mathrm{C}$, and after $2 \mathrm{~h}$ of incubation at $20^{\circ} \mathrm{C}$ (Table 1). Disease progress was similar at 15 and $20^{\circ} \mathrm{C}$, except for the periods between 8-, 10-, and 12-h leaf wetness periods. Disease severity was significantly higher on plants incubated at 25 compared with $30^{\circ} \mathrm{C}$ after leaf wetness periods of $6 \mathrm{~h}$ and 12 to $24 \mathrm{~h}$ (Table 1). Maximum disease severity of more than $80 \%$ was observed at 25 and $30^{\circ} \mathrm{C}$ with leaf wetness periods of $48 \mathrm{~h}$.

A regression model was developed to predict the form of dependence of disease severity $\left(L_{D S}=\right.$ logit transformed disease severity) on temperature $(T)$ and leaf wetness duration $(W)$. Linear terms for temperature and leaf wetness duration and their interaction were highly significant in the analysis $(P<0.0001$ for $T$ and $W, P=$ 0.0003 for $T \times W)$. None of the quadratic and cubic terms examined were significant. The relationship of temperature, leaf wetness period, and Stemphylium blight severity was described by the following model:

$L_{D S}=b_{0}+b_{1} T+b_{2} W+b_{3} T W+E$

Overall, the model predicted disease adequately. Stemphylium blight severity was under-predicted by 9 to $13 \%$ at $15^{\circ} \mathrm{C}$ with leaf wetness periods between 10 and $48 \mathrm{~h}$, and significantly over-predicted at $20^{\circ} \mathrm{C}$ after $48 \mathrm{~h}$ of leaf wetness (Fig. 4). Lower predicted values were also observed at $25^{\circ} \mathrm{C}$ with wetness periods between 4 and $24 \mathrm{~h}$, and at $30^{\circ} \mathrm{C}$ at $8 \mathrm{~h}$ leaf wetness. At 25 and $30^{\circ} \mathrm{C}$, the model predicted most rapid increases in disease severity after leaf wetness periods of 10 and $35 \mathrm{~h}$, before and beyond which the rate of disease increase declined. The model also suggests that this temperature range represents the temperature optimum, but further data beyond $30^{\circ} \mathrm{C}$ would be required to confirm this. At the other end of the temperature spectrum, very little disease development would be expected at temperatures below $10^{\circ} \mathrm{C}$ irrespective of prolonged wetness periods.

\section{DISCUSSION}

Stemphylium blight of lentil is a poorly understood disease on the Canadian prairies. Germination experiments under controlled conditions showed that conidia of $S$. botryosum from lentil germinated at temperatures ranging from a low of $5^{\circ} \mathrm{C}$ up to $30^{\circ} \mathrm{C}$. These results were confirmed on 
glass slides and on lentil leaves. A similar temperature range for conidial germination of 3 to $35^{\circ} \mathrm{C}$ was reported for the related species $A$. helianthi with an optimum at $25^{\circ} \mathrm{C}(31)$. Penetration of the lentil leaves by the pathogen was mostly through the stomata, which was also reported for alfalfa (28), and from $S$. vesicarium on onion leaves (1) and asparagus (12).

Earlier research on $S$. botryosum infecting alfalfa showed that $95 \%$ of conidia had germinated on alfalfa leaves incubated for $3 \mathrm{~h}$ at 20 to $23^{\circ} \mathrm{C}(28)$. This was significantly higher than for $S$. botryosum on lentil, where at $25^{\circ} \mathrm{C}, 20$ and $30 \%$ of conidia had germinated after 2 and $4 \mathrm{~h}$ of incubation, respectively. Higher germination rates were also observed for $S$. vesicarium incubated at $25^{\circ} \mathrm{C}$ on water agar where $50 \%$ of conidia had germinated within an hour of incubation (25).

Despite high conidial germination rates after relatively short incubation periods in wet conditions, longer wetness periods appear to be required for Stemphylium spp. to cause significant disease on host plants, in particular at suboptimal temperatures. When $S$. botryosum f. sp. lycopersici was inoculated onto tomatoes, disease severity reached 2.5 on a scale of 0 to 5 (5 representing completely wilted leaves) after 48 $\mathrm{h}$ of incubation under wet conditions at $20^{\circ} \mathrm{C}$ (5). Similarly, alfalfa plants inoculated with $S$. botryosum and incubated at 18 to $20^{\circ} \mathrm{C}$ required 4 days of misting for disease severity on leaves to reach more than $40 \%$ (8). Inoculation of asparagus spears with $S$. vesicarium also required 48 $\mathrm{h}$ of incubation in high humidity at $25^{\circ} \mathrm{C}$ for first symptoms to appear (12), and leaf wetness periods longer than $24 \mathrm{~h}$ were required for symptom development on garlic after inoculation with $S$. vesicarium and incubation at $22^{\circ} \mathrm{C}$ (4). Observations in northeastern India indicated that $18 \pm$ $2{ }^{\circ} \mathrm{C}, 85$ to $90 \% \mathrm{RH}$ in the morning, and more than $50 \% \mathrm{RH}$ in the afternoon (indicative for prolonged dew periods), as well as less than $7.7 \mathrm{~h}$ of sunshine per day were considered favorable for Stemphylium blight development in wintergrown lentil (30). Similarly, in west-central Bangladesh, Stemphylium blight development was most dramatic when maximum temperatures in the canopy ranged from 20 to $22^{\circ} \mathrm{C}$, combined with high maximum humidity above $90 \%$ RH (3). In field experiments in south-central Bangladesh, first Stemphylium blight symptoms were observed in late January or early February when maximum temperatures were between 21 and $29^{\circ} \mathrm{C}$, minimum temperatures between 13 and $15^{\circ} \mathrm{C}$, maximum $\mathrm{RH}$ between 78 and $85 \%$, and minimum RH between 48 and $63 \%$ (16). Disease severity increased steadily and was highest in March when maximum temperatures reached $35^{\circ} \mathrm{C}$ and minimum temperatures did not drop below $20^{\circ} \mathrm{C}$, combined with $\mathrm{RH}$ ranging between 78 and $100 \%$. In the current study, $48 \mathrm{~h}$ of incubation under wet conditions at $20^{\circ} \mathrm{C}$ resulted in disease levels on lentil of $44 \%$. However, at higher incubation temperatures, similar disease levels were observed after wetness periods of 6 to $8 \mathrm{~h}$. An effect of temperature similar to this was also observed when studying disease severity on onion after inoculation with $A$. porri in response to wetness duration in relation to temperature (32).

The adaptation of $S$. botryosum to particular environments was clearly demonstrated by cool (C-T) and warm (W-T) biotypes found in populations on alfalfa in western and eastern regions of the United States (9). Optimal temperature requirements of 18 to $22^{\circ} \mathrm{C}$ were identified for the $\mathrm{C}-\mathrm{T}$ biotype originating from California, whereas the W-T isolates from the eastern United States thrived at temperatures of 23 to $27^{\circ} \mathrm{C}$. The most severe symptoms of
Stemphylium blight on lentil plants in the current study were observed at temperatures of 25 and $30^{\circ} \mathrm{C}$, suggesting an optimum temperature for western Canadian lentil isolates of $S$. botryosum in this temperature range. This optimum temperature would be similar to that of field isolates in southern Bangladesh and that of the W-T biotype of alfalfa isolates. In contrast, west-central Bangladeshi lentil isolates of S. botryosum required 20 to $22^{\circ} \mathrm{C}$ for maximum infection of lentil (3), and the temperature optimum for Stemphylium blight on lentil in northern India was identified as $18 \pm 2^{\circ} \mathrm{C}$ (30). Isolates in those regions could thus represent cool biotypes of the pathogen adapted to the environmental conditions of lentil grown throughout the winter in those locations. More isolates need to be tested to confirm whether lentil isolates of $S$. botryosum can

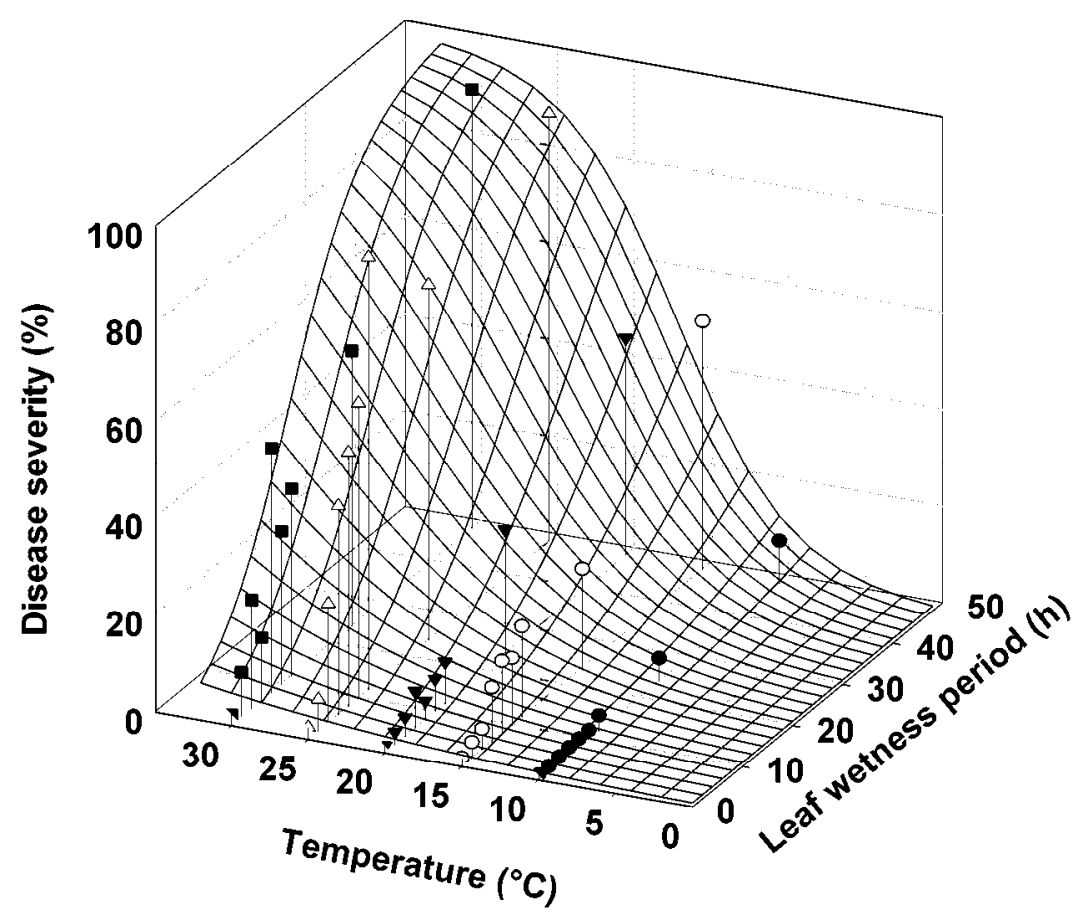

Fig. 4. Severity of Stemphylium blight after inoculation of lentil cultivar CDC Milestone with Stemphylium botryosum isolate SB19 and incubation for up to $48 \mathrm{~h}$ at temperatures of $10,15,20,25$, and $30^{\circ} \mathrm{C}$. Symbols represent observed disease severity. Response surface mesh plot represents predicted germination based on the function $L_{D S}=-4.7547+0.003096 T+0.0708 \mathrm{~W}+0.004307 T W$, where $L_{D S}$ is logit transformed disease severity, $T$ is temperature, and $W$ is wetness duration.

Table 1. Stemphylium blight severity (back-transformed logit transformed least-squared estimates) on lentil cultivar CDC Milestone in response to incubation at different temperatures and leaf wetness periods

\begin{tabular}{lcccrr}
\hline \multirow{2}{*}{$\begin{array}{l}\text { Wetness } \\
\text { period (h) }\end{array}$} & $\mathbf{1 0}^{\mathbf{z}}$ & $\mathbf{1 5}$ & $\mathbf{2 0}$ & $\mathbf{2 5}$ & $\mathbf{3 0}$ \\
\cline { 2 - 6 } 0 & $1.17 \mathrm{a}$ & $1.73 \mathrm{ab}$ & $1.52 \mathrm{ab}$ & $2.43 \mathrm{~b}$ & $2.15 \mathrm{~b}$ \\
2 & $1.27 \mathrm{a}$ & $2.93 \mathrm{~b}$ & $2.47 \mathrm{ab}$ & $5.99 \mathrm{c}$ & $8.36 \mathrm{c}$ \\
4 & $1.47 \mathrm{a}$ & $4.12 \mathrm{~b}$ & $3.69 \mathrm{~b}$ & $22.88 \mathrm{c}$ & $20.67 \mathrm{c}$ \\
6 & $1.66 \mathrm{a}$ & $11.07 \mathrm{~b}$ & $7.31 \mathrm{~b}$ & $42.73 \mathrm{c}$ & $11.61 \mathrm{~b}$ \\
8 & $1.76 \mathrm{a}$ & $12.85 \mathrm{c}$ & $3.72 \mathrm{~b}$ & $52.26 \mathrm{~d}$ & $37.56 \mathrm{~d}$ \\
10 & $1.87 \mathrm{a}$ & $12.36 \mathrm{c}$ & $6.23 \mathrm{~b}$ & $63.10 \mathrm{e}$ & $29.81 \mathrm{~d}$ \\
12 & $3.11 \mathrm{a}$ & $17.49 \mathrm{c}$ & $8.20 \mathrm{~b}$ & $90.77 \mathrm{e}$ & $35.21 \mathrm{~d}$ \\
24 & $4.82 \mathrm{a}$ & $19.61 \mathrm{~b}$ & $23.39 \mathrm{~b}$ & $79.02 \mathrm{e}$ & $57.44 \mathrm{~d}$ \\
48 & $8.00 \mathrm{a}$ & $51.34 \mathrm{~b}$ & $44.43 \mathrm{~b}$ & $91.13 \mathrm{c}$ & $92.76 \mathrm{c}$ \\
\hline
\end{tabular}

${ }^{\mathrm{z}}$ Estimates followed by the same letter in a row are not significantly different based on LSD at $5 \%$. 
indeed be separated into two biotypes with distinct temperature optima. The present study demonstrated that low levels of disease ( 2 to $7 \%$ severity) can develop after 2 $\mathrm{h}$ of leaf wetness at 10 to $20^{\circ} \mathrm{C}$, indicating that the pathogen can cause at least some infection at low temperatures.

Predictive models used for Stemphylium spp. such as BSPcast, FAST, and TOMCAST recognize the importance of temperature and leaf wetness duration on disease severity and have been used successfully in the timely scheduling of fungicide applications $(20,23,25)$. For example, FAST incorporates hours of leaf wetness, average temperature during the wetness period, mean air temperature, hours of relative humidity greater than $90 \%$, and total precipitation into the model (21). Although this model was developed for Alternaria solani on tomato, it accurately predicted infection periods for $S$. vesicarium on pear and could reduce fungicide sprays by 28 to $38 \%$ when used to schedule fungicide applications. However, it was not accurate at forecasting disease levels (25). Even higher reductions in the number of fungicide applications of up to $60 \%$ were achieved when using TOMCAST, a model derived from FAST, to control purple spot of asparagus (23). This forecasting model relies on wetness periods and temperature to assign disease severity values.

BSPcast was specifically developed to forecast infection by $S$. vesicarium on pear by relating disease severity to temperature and daily wetness duration (20). Although isolates of $S$. vesicarium causing brown spot on pear clearly have a temperature optimum around $20^{\circ} \mathrm{C}$ compared to an optimum of 25 to $30^{\circ} \mathrm{C}$ for $S$. botryosum on lentil as determined in this study, disease progress appears to be similar, characterized by a logarithmic increase in disease severity toward the optimum temperature. This was recognized in both studies by using a $\log _{10}$ transformation in the model for brown spot on pear (24), and the logit transformation in the current model.

This study could be used for the prediction of conidial germination and disease severity at wetness duration of 0 to $48 \mathrm{~h}$ and temperatures of 5 to $30^{\circ} \mathrm{C}$ under field conditions. Further experiments beyond $30^{\circ} \mathrm{C}$ would be required to confirm that the temperature optimum for $S$. botryosum on lentil is indeed between 25 and $30^{\circ} \mathrm{C}$, and to explore to what degree infection is inhibited beyond the maximum temperature. Prolonged continuous periods of wetness are infrequent during the growing season in the Canadian prairies, particularly in the semiarid region where the majority of lentil is grown. Significant rain events often occur in the form of thunderstorms characterized by very intense rain in short periods of time, followed by dry and warm or possibly hot periods. Conidia of the related $A$. cirsinoxia, evaluated as a poten- tial bioherbicide of Canada thistle in the Canadian prairies, were shown to be well adapted to this environment and remained infectious, albeit at decreasing rates, even after five cycles of intermittent leaf wetness (14). It is likely that survival during repeated intermittent leaf wetness periods is also characteristic for conidia of $S$. botryosum, an area which therefore warrants further evaluation in the development of forecasting models.

\section{ACKNOWLEDGMENTS}

Funding for this project through the Agricultural Development Fund of the Saskatchewan Ministry of Agriculture and the Saskatchewan Pulse Growers is gratefully acknowledged.

\section{LITERATURE CITED}

1. Aveling, T. A. S., and Snyman, H. G. 1993. Infection studies of Stemphylium vesicarium on onion leaves. Mycol. Res. 97:984-988.

2. Bakr, M. A. 1991. Plant protection of lentil in Bangladesh. Pages 177-186 in: Proc. Seminar Lentil South Asia, 11-15 March. W. Erskine and M. C. Saxena, eds. ICARDA, Aleppo, Syria.

3. Bakr, M. A., and Ahmend, F. 1992. Development of stemphylium blight of lentil and its chemical control. Bangladeshi J. Plant Pathol. 8:39-40.

4. Basallote-Ureba, M. J., Prados-Ligero, A. M., and Melero-Vara, J. M. 1999. Aetiology of leaf spot of garlic and onion caused by Stemphylium vesicarium. Plant Pathol. 48:139-145.

5. Bashi, E., and Rotem, J. 1974. Adaptation of four pathogens to semi-arid habitats as conditioned by penetration rate and germinating conidium survival. Phytopathology 64:10351039.

6. Bayaa, B., and Erskine, W. 1998. Diseases of lentil. Pages 442-443 in: The Pathology of Food and Pasture Legumes. D. J. Allen and J. M. Lenné, eds. $\mathrm{CAB}$ International, Wallingford, UK

7. Bradley, D. J., Gilbert, G. S., and Parker, I. M. 2003. Susceptibility of clover species to fungal infection: The interaction of leaf surface traits and environment. Am. J. Bot. 90:857-864.

8. Cowling, W. A., and Gilchrist, D. G. 1982. Effect of light and moisture on Stemphylium leaf spot of alfalfa. Plant Dis. 66:291-294.

9. Cowling, W. A., Gilchrist, D. G., and Graham, J. H. 1981. Biotypes of Stemphylium botryosum on alfalfa in North America. Phytopathology 71:679-684.

10. Degenhardt, K. J., Petrie, G. A., and Morrall, R. A. A. 1982. Effects of temperature on spore germination and infection of rapeseed by $\mathrm{Al}$ ternaria brassicae, A. brassicicola, and A. raphani. Can. J. Plant Pathol. 4:115-118.

11. Emery, K. M., and English, J. T. 1994. Development of foliar diseases of alfalfa in relation to microclimate, host growth, and fertility. Phytopathology 84:1263-1269.

12. Falloon, P. G., Falloon, L. M., and Grogan, R. G. 1987. Etiology and epidemiology of Stemphylium leaf spot and purple spot of asparagus in California. Phytopathology 77:407-413.

13. Graham, J. H. 1957. A Stemphylium disease on ladino white clover. Phytopathology 47:213-215.

14. Green, S., and Bailey, K. L. 2000. Influence of moisture and temperature on infection of Canada thistle by Alternaria cirsinoxia. Plant Dis. 84:1126-1132.

15. Horsfall, J. G., and Barratt, R. W. 1945. An improved grading system for measuring plant diseases. Phytopathology 35:65

16. Huq, M. I., and Khan, A. Z. M. N. A. 2008. Epidemiology of Stemphylium blight of lentil. Bangladesh J. Sci. Industrial Res. 43:513-520.
17. Jakhar, S. S., Duhan, J. C., and Suhag, L. S 1996. Studies on conidial germination and factors affecting disease development of Stemphylium blight of onion. Indian Phytopathol. 49:362-365

18. Koike, S. T., Henderson, D. M., and Butler, E. E. 2001. Leaf spot disease of spinach in California caused by Stemphylium botryosum. Plant Dis. 85:126-130.

19. Littell, R. C., Milliken, G. A., Stroup, W. W., Wolfinger, R. D., and Schabenberger, O. 2006 SAS for Mixed Models. 2nd ed. SAS Institute, Cary, NC, USA

20. Llorente, I., Vilardell, P., Bugiani, R., Gherardi, I., and Montesinos, E. 2000. Evaluation of BSPcast disease warning system in reduced fungicide use programs for management of brown spot of pear. Plant Dis. 84:631-637.

21. Madden, L., Pennypacker, S. P., and MacNab, A. A. 1978. FAST, a forecast system for Alternaria solani on tomato. Phytopathology 68:1354-1358.

22. Madden, L.V., Hughes, G., and van den Bosch, F. 2007. The Study of Plant Disease Epidemics. American Phytopathological Society, St Paul, MN, USA.

23. Meyer, M. P., Hausbeck, M. K., and Podolsky, R. 2000. Optimal fungicide management of purple spot of asparagus and impact on yield Plant Dis. 84:525-530.

24. Montesinos, E., Moragrega, C., Llorente, I., Vilardell, P., Bonaterra, A., Ponti, I., Bugiani, R., Cavanni, P., and Brunelli, A. 1995. Development and evaluation of an infection mode for Stemphylium vesicarium on pear based on temperature and wetness duration. Phytopathology 85:586-592.

25. Montesinos, E., and Vilardell, P. 1992. Evaluation of FAST as a forecasting system for scheduling fungicide sprays for control of Stemphylium vesicarium on pear. Plant Dis. 76:1221-1226.

26. Morrall, R. A. A. 1997. Evolution of lentil diseases over 25 years in western Canada. Can. J. Plant Pathol. 19:197-207.

27. Morrall, R. A. A., Carriere, B., Pearse, C. Schmeling, D., and Thomson, L. 2006. Seedborne pathogens of lentil in Saskatchewan in 2005. Can. Plant Dis. Surv. 86:104-106.

28. Pierre, R. E., and Millar, R. L. 1965. Histology of the pathogen-suscept relationship of Stemphylium botryosum and alfalfa. Phytopathology 55:909-914.

29. Schabenberger, O., and Pierce, F. J. 2002. Contemporary statistical models for the plant and soil sciences. CRC Press, Boca Raton, FL, USA

30. Sinha, J. N., and Singh, A. P. 1993. Effect of environment on the development and spread of stemphylium blight of lentil. Indian Phytopathol. 46:252-253.

31. Somasundara, B., and Anilkumar, T. B. 1987. Factors affecting conidium germination in $\mathrm{Al}$ ternaria helianthi. Zentralblatt Mikrobiol. 142:169-620.

32. Suheri, H., and Price, T. V. 2000. Infection of onion leaves by Alternaria porri and Stemphylium vesicarium and disease development in controlled environments. Plant Pathol. 49:375-382.

33. Vloutoglou, I., Fitt, B. D. L., and Lucas, J. A. 1996. Germination of Alternaria linicola conidia on linseed: Effects of temperature, incubation period, leaf wetness and light regime. Plant Pathol. 45:529-539.

34. Zimmerman, D. L., and Núñez-Antón, V. 1997. Structural antedependence models for longitudinal data. Pages 63-76 in: Modelling Longitudinal and Spatially Correlated Data, Methods, Applications, and Future Directions. Lecture Notes in Statistics 122. T. G. Gregoire, D. R. Brillinger, P. J. Diggle, E. RussekCohen, W. G. Warren, and R. D. Wolfinger, eds. Springer-Verlag, New York. 